\title{
Refleksi Pelaksanaan Pilkada Serentak 2020: Suatu Kajian Tentang Demokrasi di Indonesia
}

\author{
Igam Arya Wada \\ Fakultas Hukum, Universitas Surabaya, igamaryawada@gmail.com
}

\begin{abstract}
In 2020, Indonesia is mandated by Law No. 10 of 2016 on the second amendment to Law No. 1 of 2015 on the Election of Governors, Regents, and Mayors to conduct simultaneous elections. But on the other hand, the Government of Indonesia also has a policy in an effort to control cases of the Covid-19 pandemic in Indonesia by limiting people to gather. This is a dilemma, that the key to the success of the election is one of them is seen from the level of participation of the people who attended to vote. However, this is doubtful considering that the public still has fears of being exposed to the covid-19 virus. Thus, this article aims to see the success of the implementation of the Sentak Election in 2020 judging from the aspect of democracy, especially public participation. In an effort to achieve this goal, this article was written with literature research that emphasizes the legislative approach and conceptual approach. Therefore, this article concludes that the implementation of simultaneous elections in 2020 still presents many problems in various aspects and still many received rejection from the public, so that it has an impact on the level of participation.
\end{abstract}

Keywords: Pemilu 2020; democracy; Covid-19

\begin{abstract}
Abstrak
Pada tahun 2020, Indonesia diamanatkan oleh Undang Nomor 10 Tahun 2016 tentang perubahan kedua atas Undang-Undang Nomor 1 Tahun 2015 tentang Pemilihan Gubernur, Bupati, dan Walikota untuk melaksanakan pemilihan umum serentak. Namun di sisi lain, Pemerintah Indonesia juga punya kebijakan dalam upaya mengendalikan kasus pandemic Covid-19 di Indonesia dengan membatasi masyarakat untuk berkumpul. Hal ini menjadi dilemma, bahwa kunci dari pada keberhasilan pemilu adalah salah satunya dilihat dari tingkat partisipasi masyarakat yang hadir untuk memberikan suaranya. Tetapi, hal tersebut diragukan mengingat bahwa masyarakat masih ada ketakutan akan terkena virus covid-19. Sehingga, artikel ini bertujuan untuk melihat keberhasilan pelaksanaan Pemilu Sentak tahun 2020 dilihat dari aspek demokrasi, khususnya partisipasi masyarakat. Dalam usaha untuk mencapai tujuan tersebut, artikel ini ditulis dengan penelitian kepustakaan yang menekankan pada pendekatan perundang-undangan dan pendekatan konseptual. Maka dari itu, artikel ini menyimpulkan bahwa pelaksanaan pemilu serentak tahun 2020 masih menghadirkan banyak permasalahan diberbagai aspek serta masih banyak mendaptkan penolakan dari masyarakat, sehingga hal tesebut berdampak pada tingkat partisipasinya.
\end{abstract}

Kata Kunci: Pemilu 2020; Demokrasi; Covid-19

\section{Pendahuluan}

\section{Jurnal YUSTIKA} Media Hukum dan Keadilan Fakultas Hukum Universitas Surabaya Vol. 24 No. 02, Desember 2021 P-ISSN: 1410-7724

Penerapan sistem demokrasi di Indonesia merupakan perwujudan dari keinginan bangsa indonesia yang dilaksanakan dengan berlandaskan pada Pancasila dan Undang-Undang Dasar Negara Republik Indonesia Tahun 1945 (UUD NRI 1945). Pelaksanaan demokrasi dimaksudkan untuk mengedepankan suara rakyat dalam hal pelaksanaan negara sebagai penentu arah tujuan negara. Rakyat merupakan pemegang kedaulatan tertinggi di dalam sebuah negara, sebagaimana yang telah dituangkan pada ketentuan Pasal 1 ayat (2) UUD NRI 1945. Kedaulatan rakyat dalam hal pelaksanaan negara yang paling nyata ialah kedaulatan dalam hal menentukan 
seorang pemimpin di dalam sebuah negara, salah satunya ialah memilih pemimpin di daerah atau kepala daerah. Sebagaimana telah ditentukan pada ketentuan Pasal 18 ayat (4) UUD NRI 1945 yang pada intinya menyebutkan bahwa Gubernur, Bupati, dan Walikota masing-masing dipilih secara demokratis.

Ketentuan dalam pasal tersebut dapat dilihat bahwa yang dimaksud dengan terpilihnya kepala daerah ialah dari rakyat, baik itu secara langsung ataupun diwakilkan oleh Dewan Perwakilan Rakyat Daerah (DPRD). Dengan demikian dalam hal pemilihan kepala daerah dapat dilakukan secara langsung oleh rakyat ataupun melalui wakilnya yakni DPRD (M. Lutfi, 2014). Namun, pengertian demokrasi sendiri mengalami perkembangan yang dimanifestasikan melalui ketentuan pada Undang-Undang Nomor 1 tahun 2015 tentang Penetapan Peraturan Pemerintah Pengganti Undang-Undang Nomor 1 Tahun 2014 Tentang Pemilihan Gubernur, Bupati, Dan Walikota Menjadi Undang-Undang (UU No 1 Tahun 2015). Pada bagian konsideran huruf c undang-undang tersebut, menyatakan bahwa pelaksanaan pemilihan kepala daerah haruslah dipilih oleh rakyat secara langsung. Sehingga berkaitan dengan pemilihan kepala daerah hanya dapat dilakukan secara langsung oleh rakyat tanpa diwakilkan oleh orang lain. Sebagaimana Pelaksanaan pemilihan umum kepala daerah secara langsung oleh rakyat, diharapkan dapat menjadi salah satu instrumen untuk mewujudkan demokrasi yang kemudian dapat menciptakan pemerintah yang lebih demokratis.

Berkaitan dengan Pemilihan Umum Kepala Daerah (PILKADA) secara langsung inilah yang kemudian menjadi permasalahan pada pelaksanaan PILKADA 2020, dimana sesuai jadwal rutin Indonesia memiliki agenda untuk menyelenggarakan Pilkada Serentak pada tanggal 23 September 2020. Hal ini pun telah diatur melalui ketentuan pada Pasal 201 ayat (6) UndangUndang Nomor 10 Tahun 2016 tentang Perubahan Kedua atas Undang-Undang Nomor 1 Tahun 2015 tentang Pemilihan Gubernur, Bupati, dan Walikota (UU No 10 tahun 2016). Dengan melihat kondisi yang ada, pelaksanaan PILKADA serentak 2020 harus ditunda sebab pemerintah merasa belum siap untuk melaksanakannya, mengingat bahwa indonesia sedang dihadapkan pada bencana Covid-19. Pemerintah harus menunda pelaksanaan PILKADA tersebut menjadi tanggal 9 Desember 2020, sebagaimana di atur pada Peraturan Pemerintah Pengganti Undang-Undang Nomor 2 Tahun 2020 tentang Pemilihan Gubernur, Bupati, dan Walikota (Perpu 2 Tahun 2020). Pemerintah juga telah menetapakan bencana virus corona sebagai bencana nasional yang juga ditegaskan dalam Keputusan Presiden Nomor 12 Tahun 2020 Tentang Penetapan Bencana Nonalam Penyebaran Corona Virus Desease 2019 (Covid-19) Sebagai Bencana Nasional. Penundaan Pemilihan Kepala Daerah menjadi Desember 2020 dirasa masih menuai pro dan kontra, dimana menjelang bulan Desember 2020 jumlah kasus positif COVID-19 terus meningkat secara nasional. Hal ini memunculkan banyak kekhawatiran dari berbagai pihak, mulai dari kalangan pejabat hingga masyarakat. Serta kebijakan pelaksanaan PILKADA serentak 2020, tentu akan menciderai kualitas demokrasi Indonesia. Jika dilhat dalam beberapa aspek yang dipaparkan sebelumnya, PILKADA serentak tahun 2020 tetap dilaksanakan sesuai dengan rencana. Permasalahan terkait Pilkada Serentak 2020 memunculkan beberapa problematika terkait rencana pelaksanaan PILKADA serentak tahun 2020. Mulai dari angka penularan virus corona yang kian melambung, hingga partisipasi masyarakat yang rendah dalam PILKADA 2020. Apakah pelaksanaan PILKADA 2020 justru berjalan dengan baik atau sebaliknya semakin menimbulkan permasalahan diberbagai hal.

Berdasarkan pemikiran di atas, penulis tertarik untuk meneliti dalam sebuah kajian akademis berupa penulisan karya ilmiah Jurnal, untuk mengetahui bagaimana pelaksanaan 
Jurnal Yustika

Vol. 24 No. 02, Des 2021

Halaman | 93

Refleksi

Pelaksanaan

Pilkada Serentak 2020: Suatu Kajian Tentang Demokrasi di Indonesia

Igam Arya Wada
Pilkada 2020 dan kaitannya dengan kualitas demokrasi, dengan judul "Refleksi Pelaksanaan Pilkada Serentak 2020: Suatu Kajian Tentang Demokrasi di Indonesia“. Proses Pemilihan Kepala Daerah serentak tahun 2020 tentu menyisakan sejumlah permasalahan di dalamnya. Salah satu hal penting yang mungkin dilupakan oleh pemerintah yaitu terkait hak berdemokrasi dalam masa Pandemi Covid-19. Sehingga demokrasi yang merupakan hak warga negara terkesan di reduksi dengan sejumlah aturan terkait pelaksanaan Pilkada Serentak 2020.

\section{Pembahasan}

\subsection{Relevansi Proses Pelaksanaan Pilkada Serentak Tahun 2020}

Pilkada serentak merupakan upaya untuk menciptakan local accountability, political equity dan local responsiveness. Dengan begitu, demokratisasi di tingkat lokal terkait erat dengan tingkat partisipasi, dan relasi kuasa yang dibangun atas dasar pelaksanaan azas kedaulatan rakyat (Arifulloh, 2015). Sehingga berkaitan dengan pelaksanaan pemilihan kepala daerah tidak serta merta hanya untuk memilih seorang pemimpin saja, melainkan tentang apakah masyarakat mau berpartisipasi atau tidak. Sebab partisipasi rakyat sebagai unsur terpenting dalam pelaksanaan PILKADA tersebut. Mengingat bahwa pelaksanaan PILKADA merupakan perwujudan dari negara demokrasi yang menempatkan rakyat sebagai pemegang kedaulatan tertinggi. Sejatinya hal ini menyiratkan bahwa penguasa atau pemimpin yang terpilih merupakan keputusan suara rakyat pada wilayah pemilihan tersebut. Sebab bagaimana mungkin seseorang memimpin, di sebuah wilayah yang tidak menginginkan pemimpin tersebut. Itu sebabnya dalam pelaksanaan pesta demokrasi pada PILKADA, masyarakat didorong untuk tidak melakukan Golput (Golongan Putih), artinya jangan sampai seorang pemimpin terpilih dengan suara yang kurang dari 50\% suara rakyat. Meskipun Golput masih saja menjadi tantangan berbagai negara, bahkan di negara maju seperi Amerika Serikat. (Mulyadi, 2019)

Konsep pelaksanaan suatu PILKADA yang demikian merupakan suatu konsekuensi sebagai negara demokrasi. Sebagaimana pengertian demokrasi ialah prinsip dasar hidup bernegara yang menempatkan rakyat dalam posisi berkuasa (government or role by people) sehingga pada tingkat terakhir rakyat memberikan ketentuan mengenai kehidupannya, termasuk dalam menilai kebijaksanaan negara karena kebijaksanaan tersebut menentukan kehidupan rakyat (Arifulloh, 2015). Perwujudan demokrasi itu sediri dapat terlihat melalui tingkat partisipasi politik dari masyarakat pada setiap Pemilihan Umum (Ni Ketut Arniti, 2020). Sehingga indonesia yang berdiri sebagai negara demokrasi tentunya wajib mencerminkan kedaulatan rakyat di dalam proses PILKADA yang dilaksanakan, dimana pemilihan tersebut jangan sampai mengesampingkan partisipasi rakyat. Sebab tanpa partisipasi juga berarti tanpa suara sehingga indikator keberhasilan demokrasi yang merupakan partisipasi masyarakat dalam pemilu yang secara langsung terlibat dalam memilih pemimpin dan wakil-wakil rakyat di parlemen tidak akan tercapai. (Mulyadi, 2019)

Berdasarkan pada ketentuan Pasal 201 ayat (6) Undang-Undang Nomor 10 Tahun 2016 tentang perubahan kedua atas Undang-Undang Nomor 1 Tahun 2015 tentang Pemilihan Gubernur, Bupati, dan Walikota menentukan bahwa pelaksanaan PILKADA serentak akan dilaksanakan pada tanggal 23 september 2020. Hal ini sejalan dengan kegiatan rutin negara bahwa setiap 5 tahun sekali akan dilaksanakan pesta demokrasi melalui pemilihan kepala daerah. Tentu saja ini juga sebagai pencerminan dari jiwa demokrasi Indonesia. Namun, pada tanggal 2 maret 2020 pemerintah mengumumkan secara resmi kasus COVID-19 (Corona Virus 
Disease) pertama di Indonesia (Sukur et. al, 2020). Sebagaimana kita mengetahui bahwa virus ini pertama kali terdengar di wuhan negara China yang juga sudah mulai menyebar ke berbagai negara termasuk Indonesia. Salah satu wilayah Indonesia yang terdampak ialah Jawa Timur sebagai wilayah kasus penyebaran terbanyak, dimana hingga pada tanggal 01 oktober 2020 tercatat ada 223 kasus (Sukur et. al, 2020). Menilik pada permasalahan ini pemerintah mulai menerapkan berbagai aturan untuk menekan tingkat penyebaran virus corona. Mulai dari penerapan Lock down (menghentikan aktifitas) selama 3 hari, Pembatasan Sosial Berskala Besar (PSBB), mengarahkan masyarakat untuk bekerja dan sekolah dari rumah, hingga pada mewajibkan masyarakat untuk menggunakan masker, cuci tangan dan jaga jarak. Tetapi mekanisme demikian masih belum dapat menekan angka peningkatan penyebaran virus corona. Hal ini pun kemudian menimbulkan banyak permasalahan dalam berbagai bidang, baik itu sosial, ekonomi, dan politik.

Permasalahan pemerintah terkait penyebaran virus corona yang tak kunjung usai nyatanya pun memberikan dampak pada terselenggaranya PILKADA Serentak Tahun 2020. Sejalan dengan ketentuan pada Perpu 2 Tahun 2020, PILKADA ditunda menjadi tanggal 9 Desember 2020. Peraturan ini sekaligus mengumumkan bahwa penyebaran virus corona dinyatakan sebagai bencana nasional. Pemerintah melakukan penundaan pelaksanaan selama 3 bulan karena dirasa tidak memungkinkan untuk melaksanakan PILKADA pada bulan september mengingat indonesia baru saja dihadapkan pada bencana virus corona. Meskipun pemerintah telah melakukan penundaan hingga pada bulan Desember, nyatanya tidak sedikit yang menolak untuk melaksanakan PILKADA pada tahun 2020. Mulai dari kalangan pejabat, masyarakat, hingga pelaksana PILKADA banyak mengusulkan untuk menunda pelaksanaannya sampai Indonesia berada pada kondisi yang siap.

Penolakan untuk menunda lagi pelaksanaan PILKADA dilandaskan pada: Pertama, Kesehatan masyarakat yang akan terancam, sebab PILKADA berpotensi besar untuk meningkatkan kluster penyebaran virus corona. Sebagaimana dikatakan oleh Erick Thohir yang merupakan Ketua Pelaksana Komite Penanganan Covid-19 dan Pemulihan Ekonomi Nasional bahwa kesehatan diutamakan dahulu (Kompas, 2021). Ditambah lagi dari KPU sendiri belum melakukan sosialisasi dan juga simulasi kepada masyarakat. Kedua, Penyelenggara PILKADA nyatanya juga belum memiliki mekanisme pemilihan yang sesuai dengan kondisi pandemi saat itu. Sehingga dengan mekanisme yang tidak siap justru berpotensi akan meningkatkan kecurangan dalam proses PILKADA. Ketiga, Memiliki potensi peningkatan Golput dikarenakan banyak masyarakat yang takut untuk mengikuti PILKADA 2020. Sebagaimana dibuktikan dari hasil survey charta politica yang menunjukkan bahwa 54,2 persen responden tidak setuju PILKADA 2020 dilaksanakan (Kompas, 2021).

Hal ini pun sejalan dengan survey yang dilakukan oleh KPU yang menyatakan bahwa terdapat penurunan partisipasi masyarakat pada PILKADA 2020 jika dibandingkan tahun-tahun sebelumnya, yang mana hal tersebut disampaikan oleh komisioner KPU RI, Dewa Kade Wiarsa Raka Sandi (Liputan 6, 2021). Namun, meski demikian kebijakan pemerintah saat itu telah matang dimana pemerintah tetap melaksanakan PILKADA dengan landasan pelaksanaan PILKADA akan dilakukan dengan menggunakan mekanisme sesuai dengan Protokol kesehatan. Penyelenggara pemilihan umum dan pemerintah saat itu pun mulai bekerjasama untuk menyukseskan pelaksanaan PILKADA 2020. Meskipun diketahui bahwa Pilkada Serentak masih dapat ditunda dengan menunjuk Penjabat Kepala Daerah, namun dalam hal ini dengan banyaknya wilayah yang akan melaksanakan pemilihan tentunya juga akan banyak menunjuk 
Jurnal Yustika

Vol. 24 No. 02, Des 2021

Halaman I 95

Refleksi

Pelaksanaan

Pilkada Serentak 2020: Suatu Kajian

Tentang Demokrasi di Indonesia

Igam Arya Wada
Penjabat Kepala Daerah di masing-masing wilayah. Selain itu kondisi formal dimana Penjabat Kepala Daerah yang memegang jabatan pemimpin daerah juga tidak boleh terlalu lama karena adanya keterbatasan kewenangan yang dimili dibandinga seorang Kepala Daerah yang terpilih secara demokratis.

Pelaksanaan PILKADA serentak pada tahun 2020 dimulai dari proses pendaftaran peserta PILKADA. Namun ditemukan pada saat pendafataran PILKADA, KPU mendata bahwa terdapat 243 peserta yang melanggar protokol kesehatan. Antara lain: Sejumlah pendukung salah satu pasangan bakal calon kepala daerah Makassar melakukan konvoi menggunakan kendaraan menuju ke kantor Komisi Pemilihan Umum (KPU), peserta dari berbagai wilayah membawa pendukung beramai-ramai pada saat pendaftaran di KPU, keributan yang terjadi di Jawa tengah antar para pedukung, serta ditemukannya peserta yang mengadakan konser kampanye yang mengumpulkan halayak ramai (Kompas, 2020). Padahal jauh sebelum itu, pemerintah telah mengumumkan mengenai kewajiban untuk mematuhi protokol kesehatan sesuai himbauan dari Satgas Covid-19, yaitu salah-satunya untuk tidak menyebabkan kerumunan massa. Tetapi hal tersebut enggan dipatuhi oleh para peserta disebabkan semangat peserta hanya ditujukan pada pemenangan PILKADA 2020. Disamping itu, KPU pada saat itu belum memiliki mekanisme sanksi bagi peserta pemilu yang tidak mematuhi protokol kesehatan. Akibatnya tidak ada sanksi yang jelas bagi peserta yang melanggar protokol kesehatan tersebut.

Hingga saat kejadian tersebut terliput oleh media, pemerintah menuai banyak kritik dari masyarakat. Hal tersebut tidak dapat dipungkiri, dimana disatu sisi pemerintah mengarahkan masyarakat untuk bekerja dan bersekolah dari rumah tetapi di sisi lain pemerintah mengizinkan kurumunan akibat penyelenggaraan PILKADA. Akhirnya KPU pun kemudian mulai memberikan teguran kepada peserta yang melanggar hingga pada ancaman diskualifikasi jika ada peserta PILKADA yang melanggar lagi.

Selain itu, pada penyelenggaraan PILKADA serentak 2020 nyatanya belum seluruh tempat pemungutan suara (TPS) memenuhi mekanisme sesuai protokol kesehatan. Hal ini disampaikan oleh Bawaslu (Badan Pengawas Pemilu) bahwa 1.454 TPS tidak memiliki fasilitas cuci tangan (JPNN, 2021). Padahal fasilitas itu seharusnya menjadi kewajiban yang harus dipatuhi selama pandemi COVID-19, terutama pada tiap TPS yang merupakan tempat orang berlalu-lalang selama masa PILKADA. Bahkan permasalahan yang lebih buruk ialah Bawaslu juga menemukan bahwa Petugas Kelompok Penyelenggara Pemungutan Suara (KPPS) yang terpapar COVID-19, tetapi masih bertugas di TPS. Ini terjadi di 1.172 TPS di seluruh Indonesia (JPNN, 2021). Justru hal ini yang nantinya menjadi pemicuh tingginya penyebaran virus corona di Indonesia. Sebagaimana kekhawatiran masyarakat sebelumnya bahwa PILKADA serentak 2020 dapat menjadi peluang empuk untuk peningkatan penyebaran virus corona di Indonesia. Sehingga menjadi pertanyaan, apakah penundaan tiga bulan terhadap pelaksanaan PILKADA serentak sama sekali tidak menghasilkan suatu mekanisme pengawasan protokol ksehatan dalam penyelenggaraan PILKADA. Padahal pemerintah dalam menyelenggarakan PILKADA serentak 2020 memberikan jaminan bahwa pelaksanaan PILKADA akan tetap dilakukan dengan menaati protokol kesehatan sesuai himbauan dari Satgas Covid-19.

Penyelenggaraan PILKADA serentak tahun 2020 dilaksanakan di 270 daerah, dengan 100,3 juta orang DPT. Sebelumnya KPU memberikan target bahwa partisipasi masyarakat untuk mengikuti PILKADA serentak tahun 2020 dapat mencapai 77,5 persen (Kompas, 2021). Namun tampaknya penyelenggaraan PILKADA serentak 2020 yang dilakukan ditengah pandemi covid19 memberikan pengaruh besar pada partisipasi masyarakat. Sebagaimana kekhawatiran 
sebelumnya, bahwa banyak masyarakat yang takut untuk ikut pemilihan pada PILKADA serentak 2020 dikarenakan angka penyebaran virus corona terus meningkat setiap tahunnya.

Hal tersebut dibuktikan dengan jumlah masyarakat yang melakukan Golput atau tidak memberikan suara pada PILKADA serentak yang tinggi. Medan, Depok, Kediri, Tangerang Selatan dan Denpasar, yang merupakan daerah dengan golput tertinggi. Misalnya kasus yang terjadi di Medan, pada hasil rekapitulasi penghitungan suara ditetapkan bahwa pasangan Bobby-Aulia memperoleh 393.327 suara atau 53,45 persen dari suara sah. Sedangkan pasangan Akhyar Nasution-Salman Alfarisi memperoleh 342.580 suara atau 46,55 persen. Sehingga jika ditotal maka suara sah mencapai 735.907 suara, sedangkan yang tidak sah 12.915 suara. Maka total keseluruhan terdapat 748.882 orang yang menggunakan hak pilihnya. Padahal seharusnya jumlah DPT di Medan ialah 1.635.846 total pemilih. Artinya terdapat sebanyak 886.964 orang atau 54,22 persen dari 1.635.846 total pemilih yang tidak menggunakan hak suaranya pada PILKADA serentak tahun 2020 (Merdeka, 2021). Begitu juga yang terjadi di Depok bahwa terdapat 451.625 orang yang tidak menggunakan hak suaranya, 623.052 DPT dikediri, 976.019 orang di Tangerang, kemudian di denpasar hanya 240.261 orang yang menggunakan hak suaranya dari 444.929 DPT (Merdeka, 2021). Hal ini menunjukkan bahwa apa yang menjadi kekhawatiran sebelumnya telah terjawab dimana masyarakat enggan untuk berpartisipasi dalam memilih di PILKADA serentak tahun 2020. Padahal dalam sebuah negara demokrasi, partisipasi masyarakat merupakan salah satu unsur terpenting dalam menyelenggarakan PILKADA. Sehingga menjadi pertanyaan, bagaimana mungkin seorang pemimpin dapat memimpin di daerah disaat lebih dari 50 persen masyarakat tidak memilih pemimpin tersebut. Sehingga dalam konteks seperti ini siapakah yang dapat disalahkan. Apakah rakyat karena tidak mengahdiri PILKADA serentak atau Pemerintah yang melaksanakan PILKADA di tengah pandemi covid-19.

Pada dasarnya dalam sebuah negara yang mengamanatkan diri sebagai negara demokrasi, haruslah ada jaminan terhadap pemilihan dalam pemilu yang juga tidak terlepas dari konsep Hak Asasi Manusia itu sendiri. Sedikit tragis tapi nyata, dimasa pandemi yang masih meluas saat itu, pemerintah memikirkan bagaimana pelaksanaan pilkada tetap dilakukan. Kalau pemerintah menyatakan bahwa hal tersebut dilakukan untuk memberikan ruang untuk berdemokrasi. Nyatanya dari sejumlah indeks demokrasi, Indonesia merupakan negara yang telah masuk dalam kategori flawed democracy, bahkan sejumlah indeks lain fragile state indeks, ataupun indeks demokrasi yang dibuat dari laporan hasil penelitian di human rights watch, kontras, the economist intelligent unit (EIU) yang juga sering dijadikan acuan terkait indeks demokrasi. Ternyata di tahun 2020 indeks demokrasi Indonesia juga tidak begitu baik. Adanya beberapa penyebab yang timbul, pada dasarnya dipengaruhi oleh menurunnya aspek kebebasan sipil, aspek hak-hak politik, dan aspek demokrasi sehingga demokrasi yang ada di indonesia menjadi sebuah kajian reflektif dalam penyelenggaraan pemilu serentak yang tentunya juga patut dipertanyakan kembali karena hilangnya hak politik masyarakat disebabkan oleh adanya pandemi Covid-19 dilihat dari beberapa data sebelumnya.

\subsection{Cerminan Demokrasi Dalam Pilkada Serentak 2020}

Pada hakikatnya tujuan dari pelaksanaan PILKADA Serentak memanglah baik yakni sebagai bentuk perwujudan demokrasi. Namun, yang terpenting ialah jangan sampai pelaksanan PILKADA ini dilakukan pada waktu yang tidak tepat. Sebab hal tersebut nantinya akan mempengaruhi kualitas dari pelaksanaan demokrasi dalam PILKADA. Pada akhirnya, bukan mewujudkan demokrasi melainkan menciderai demokrasi sendiri. Sebagaimana telah dijelaskan 
Jurnal Yustika

Vol. 24 No. 02, Des 2021

Halaman | 97

Refleksi

Pelaksanaan

Pilkada Serentak 2020: Suatu Kajian

Tentang Demokrasi di Indonesia

Igam Arya Wada

sebelumnya bahwa berbicara mengenai PILKADA serentak tahun 2020, dihadapkan pada sebuah tantangan baru yakni bencana penyebaran virus covid-19 yang telah mengahantui seluruh belahan dunia termasuk Indonesia. Sehingga menimbulkan pertanyaan bagaimanakah kualitas demokrasi negara kita saat ini jika berkaca pada pelaksanaan PILKADA serentak tahun 2020.

Membahas mengenai kualitas demokrasi pada PILKADA Serentak tahun 2020, akan dilihat dari 2 hal yaitu Pertama, demokrasi berhubungan dengan tingkat partisipasi politik masyarakat. Semakin tinggi partisipasi politik masyarakat, maka semakin tinggi kadar Demokrasi Negara tersebut (Panjaitan, 2001). Jika melihat terkait dengan hal tersebut, banyak sedikitnya masyarakat yang berpatisipasi dalam penyelenggaraan PILKADA Serentak tahun 2020 akan mempengaruhi kualitas dari demokrasi sendiri. Sebagaimana telah dijelaskan sebelumnya, kebijakan pemerintah untuk tetap melaksanakan PILKADA 2020 nyatanya telah mendapat penolakan dari masyarakat. Kemudian hal ini dibuktikan dengan jumlah Golput atau orang yang tidak memberikan hak suaranya pada saat proses pemilihan kepala daerah. Penurunan jumlah partisipasi masyarakat ini dapat berimplikasi dari tingginya penyebaran virus corona setiap harinya di Indonesia. Bahkan lebih tinggi dari tingkat kematian Amerika Serikat dan negara ASEAN lainnya. Namun, pemerintah tetap melaksanakan PILKADA serentak pada tahun 2020. Jika kita beranjak ke pengertian demokrasi ialah prinsip dasar hidup bernegara yang menempatkan rakyat dalam posisi berkuasa (government or role by people) sehingga pada tingkat terakhir rakyat memberikan ketentuan mengenai kehidupannya, termasuk dalam menilai kebijaksanaan negara karena kebijaksanaan tersebut menentukan kehidupan rakyat (Panjaitan, 2001.

Sejatinya pemerintah sendiri telah mengabaikan prinsip demokrasi dimana rakyat sebagai penentu dalam hal kebijaksanaan negara. Selain itu partisipasi seharusnya juga mencakup peran serta dalam proses perencanaan, pelaksanaan, evaluasi, dan penerimaan manfaat pembangunan dengan mempertimbangkan otonomi dan kemandirian masyarakat (Muluk, 2005). Justru dengan pemerintah mengabaikan penolakan masyarakat artinya pemerintah sendiri telah mengabaikan partisipasi masyarakat dalam hal penyelenggaraan negara, dimana kemudian berakibat pada partisipasi masyarakat di PILKADA menurun. Selain itu, Partisipasi ini juga berkaitan penting dengan pemimpin yang terpilih. Bagaimana mungkin seorang terpilih sebagai pemimpin dengan suara yang lebih sedikit dibandingkan suara masyarakat yang tidak memilih. Sebagaimana ditemukan di Medan, Depok, Tangerang, Kediri dan Denpasar. Maka hal ini juga membuktikan bahwa perwujudan demokrasi pada PILKADA Serentak tahun 2020 hanya sebatas memilih dan dipilih saja namun jauh dari makna demokratis.

Berbicara mengenai demokrasi, pada dasarnya bukan sekedar memilih dan dipilih saja. Melainkan bagaimana rakyat dalam suatu negara tersebut dapat menggunakan kedaulatannya. Jika negara melakukan sesuatu yang tidak dikehendaki rakyat, hal tersebut dapat menjadi sebuah kesewenangan dari negara. Sebagaimana disebutkan oleh Giddes, bahwa demokrasi pada dasarnya mengandung makna sistem politik dimana rakyat memegang kekuasaan tertinggi bukan raja atau bangsawan (Ghofur, 2002). Sehingga keputusan pun harusnya mengikuti suara rakyat sebagai pemegang kekuasaan tertinggi. Pada konstitusi pun nyatanya hal ini diamini melalui ketentuan pada pasal 1 ayat (2) UUD NRI 1945 yaitu: Kedaulatan berada di tangan rakyat dan dilaksanakan menurut Undang-Undang Dasar. Walau jika memang kebijakan pemerintah tersebut dilandaskan dengan tujuan yang baik, tetapi tidak dapat dikatakan baik jika nyatanya tidak sesuai dengan keinginan rakyat. Sesungguhnya, dalam konsep demokrasi partispasi 
masyarakat juga memiliki hak untuk berperan dalam hal pengambilan keputusan pada saat proses pemerintah membuat keputusan. (Azhar, 2018) Proses pengambilan keputusan pemerintah seyogianya berdasarkan pada asas keterbukaan, sehingga masyarakat memungkinkan untuk (De Haan, 1986)

1. Meeweten (ikut mengetahui);

2. Meedenken (ikut memikirkan);

3. Meespreken (bermusyawarah);

4. Meebeslissen (ikut memutuskan);

5. Mebedeslussengsrecht (hak ikut memutus).

Salah satu factor yang dapat menurunkan minat masyarakat untuk ikut berpartispasi dalam Pemilu adalah kesadaaran akan praktek pengambilan keputusan yang acapkali tidak melibatkan peran publik. Masyarakat hanya diundang untuk memberikan pilihan, setelah terpilih ditinggalkan.

Kedua, Regulasi dalam pelaksanaan Pilkada Serentak 2020. Melaksanakan sesuatu haruslah disertai dengan landasan hukum yang jelas dan terarah, dimana ini merupakan konsekuensi dari Indonesia yang merupakan negara hukum sebagaimana ditegaskan pada pasal 1 ayat (3) UUD NRI Tahun 1945. Sama halnya dengan pelaksanaan PILKADA oleh masyarakat secara langsung, nyatanya telah diatur didalam ketentuan Pasal 18 ayat (4) UUD NRI 1945 yang pada intinya menentukan bahwa Gubernur, Bupati, dan Walikota masing-masing sebagai kepala pemerintah daerah provinsi, kabupaten dan kota dipilih secara demokratis. Dipilih secara demokratis, sebagaimana yang diamanatkan dalam konstitusi diartikan dari rakyat, baik secara langsung maupun diwakili oleh Dewan Perwakilan Rakyat Daerah (DPRD). Namun, berkaitan dengan pelaksanaan demokrasi nyatanya telah mengalami perkembangan yang telah dimanifestasikan melalui Undang-Undang Nomor 15 tahun 2015. Hal ini dilandasi dari penolakan yang dilakukan masyarakat terhadap kebijakan pemilihan kepala daerah oleh DPRD. Kemudian akhirnya, berkaitan dengan pelaksanaan pemilihan kepala daerah dengan demokrasi, undang-undang positif kita mengatur bahwa hal tersebut harus dilaksanakan secara langsung.

Melihat hal tersebut, pelaksanaan PILKADA serentak 2020 wajib dilaksanakan dengan pemilihan secara langsung oleh rakyat. Namun tampaknya untuk melaksanakan PILKADA serentak 2020 ditengah pandemi covid-19, baik Pemerintah maupun Komisi Pemilihan Umum (KPU) belum memiliki regulasi dengan mekanisme baru. Sebagaimana regulasi tersebut haruslah berkaitan dengan mekanisme pemilihan kepala daerah, mulai dari proses pendaftaran, kampanye, pengawasan, penyelenggaraan pemilihan, penghitungan, dan lain sebagainya yang seharusnya tidak bertentangan dengan protokol kesehatan selama pandemi covid-19. Sehingga, berkaitan dengan pelaksanaan PILKADA 2020, KPU masih tetap akan menggunakan mekanisme yang sama seperti pelaksanaan PILKADA disituasi normal. Sedangkan dari sisi pemerintah, regulasi yang dijadikan landasan ialah ketentuan Pasal 201A Ayat (2) Perpu Nomor 2 tahun 2020 tentang Pemilihan Gubernur, Bupati, dan Wali Kota yang mengatur bahwa pemungutan suara dilaksanakan pada bulan Desember 2020. Namun yang perlu dipahami ialah pada bagian konsideran menimbang, Perpu Nomor 2 tahun 2020 menyatakan bahwa PILKADA tidak dapat dilaksanakan selama masih dalam bencana pandemi corona. Hal tersebut diperkuat juga pada ketentuan ayat (3), bahwa pemungutan suara dapat diundur lagi apabila pada bulan Desember pemungutan suara belum bisa dilaksanakan. Artinya, terkait pelaksanaan PILKADA serentak tahun 2020, tidak seharusnya dilaksanakan selama belum dicabutnya Perpu No 2 Tahun 2020 
Jurnal Yustika

Vol. 24 No. 02, Des 2021

Halaman I 99

Refleksi

Pelaksanaan

Pilkada Serentak 2020: Suatu Kajian

Tentang Demokrasi di Indonesia

Igam Arya Wada dan diganti dengan ketentuan hukum baru yang mengatur mengenai pelaksanaan PILKADA serentak ditengah pandemi.

Ketika PILKADA serentak tahun 2020 tetap dilaksanakan, kita dapat melihat bahwa banyak permasalahan yang ditimbulkan akibat tidak adanya regulasi yang jelas dari pemerintah dan KPU mengenai mekanisme pelaksanaan PILKADA di tengah pandemi korona. Misalnya saja pelanggaran protokol kesehatan oleh peserta pemilu, dimana hal ini terjadi karena KPU sendiri belum mengeluarkan regulasi terkait mekanisme pendaftaran dan kampanye selama pandemi virus korona. Disamping itu juga banyak ditemukan pada PILKADA 2020 petugas yang positif Covid-19 masih tetap bertugas di TPS. Sehingga hal ini bisa dicurigai sebagai salah satu pemicuh meningkatnya angka penyebaran Covid-19. Dengan begitu dapat dipahami bahwa penyelenggaraan PILKADA serentak tahun 2020 menunjukkan bahwa sejatinya pemerintah telah menyimpangi Undang-Undang Positif kita yakni UU No 6 tahun 2020, yang melarang PILKADA dilaksanakan ditengah pandemi corona dan juga mengabaikan perlindungan terhadap kesehatan masyarakat.

Sehingga melalui penjelasan diatas, dapat dilihat bahwa pelaksanaan PILKADA serentak tahun 2020 jelas memiliki banyak permasalahan. Sebagaimana telah dipaparkan sebelumnya. Justru dapat dipertanyakan, apakah yang menjadi alasan dan tujuan pemerintah untuk tetap menyelenggarakan PILKADA serentak tahun 2020 ditengah pandemi covid-19. Jika dikatakan demi kepentingan rakyat, nyatanya hal tersebut tidak relevan mengingat penyelenggaraan PILKADA tahun lalu justru sangat membahayakan kesehatan masyarakat dengan banyaknya pelanggaran terhadap protokol kesehatan. Hal ini justru menunjukkan bahwa kepentingan politik seakan lebih diutamakan dari pada kepentingan masyarakat. Pelaksanaan PILKADA 2020 bukan demi mewujudkan demokrasi, tetapi justru malah menciderai demokrasi sendiri. Sidney Hook mengatakan bahwa demokrasi yaitu sebagai bentuk pemerintahan di mana keputusan-keputusan pemerintah yang penting atau arah kebijakan di balik keputusan secara langsung didasarkan pada keputusan mayoritas yang diberikan secara bebas dari rakyat dewasa. Merujuk pada pendapat tersebut, bahwa dalam pembuatan sebuah kebijakan, pemerintah seharusnya memperhatikan suara dan kemauan rakyat. Disaat pemerintah mengabaikan suara rakyat, nyatanya disitulah terdapat pencideraan terhadap demokrasi sendiri.

Pada dasarnya bukan sesuatu hal yang tidak mungkin untuk melakukan penundaan terhadap pelaksanaan PILKADA. Undang-Undang Nomor 8 Tahun 2015 dan Peraturan Pemerintah No 6 tahun 2005 telah mengatur terkait mekanisme penundaan Pilkada. Penundaan ini bukan sebagai bentuk pencideraan terhadap hak politik atau penghapusan demokrasi, ataupun kegagalan dalam demokrasi. Melainkan, untuk mewujudkan demokrasi yang berkualitas dengan mekanisme yang aman bagi kesehatan masyarakat. Sebab dengan ditundanya pelaksanaan PILKADA pada tahun lalu, pemerintah akan memiliki cukup waktu untuk memikirkan terkait regulasi dan juga mekanisme dalam pelaksanaan PILKADA ditengah pandemi Covid-19. Namun, kenyataannya pemerintah memilih untuk tetap melaksanakannya dan malah menimbulkan banyak permasalahan. 


\section{Penutup}

\subsection{Kesimpulan}

Dari penjelasan yang telah dipaparkan oleh penulis sebelumnya, dapat dilihat bahwa pelaksanaan PILKADA serentak tahun 2020 jelas memiliki banyak permasalahan. Pertama, pelaksanaaan PILKADA serentak tahun 2020 mengalami penolakan oleh masyarakat yang kemudian berdampak pada partisipasi masyarakat yang rendah. Dibuktikan melalui tingginya jumlah masyarakat yang tidak menggunakan hak suaranya (Golput) di berbagai daerah. Kedua, terpilihnya pasangan calon kepala daerah di beberapa wilayah dengan hanya mengantongi suara yang lebih sedikit dibandingkan suara yang tidak memilih. Ketiga, Pemerintah mengabaikan penolakan masyarakat terhadap pelaksanaan PILKADA serentak ditahun 2020, padahal saat itu masyarakat dirundung ketakutan akan penyebaran virus corona yang membabi-buta. Keempat, Pemerintah tidak memiliki regulasi mengenai mekanisme pelaksanaan PILKADA ditengah pandemi covid-19, yang menyebabkan banyak pelanggaran protokol kesehatan baik oleh peserta maupun petugas penyelenggara PILKADA. Kelima, Pemerintah menyelenggarakan PILKADA serentak tahun 2020 hanya berlandaskan pada Undang-Undang Nomor 6 tahun 2020. Padahal undang-undang tersebut lahir dari Perpu Nomor 2 tahun 2020 yang melarang pelaksanaan PILKADA ditengah pandemi covid-19. Seharusnya, untuk melaksanakan PILKADA serentak tahun 2020, pemerintah harus mencabut terlebih dahulu Perpu nomor 2 tahun 2020 dan membuat landasan hukum baru mengenai penyelenggaraan PILKADA serentak ditengah pandemi covid19. Sebagaimana dijelaskan sebelumnya, bahwa pemerintah tetap memaksakan pelaksanaan Pilkada 2020, padahal Undang-Undang Nomor 8 Tahun 2015 dan Peraturan Pemerintah no 6 tahun 2005 telah memberikan mekanisme terkait penundaan pelaksanaan PILKADA 2020. Alhasil pelaksanaan Pilkada 2020 tetap berlangsung dengan menimbulkan banyak problematika.

\subsection{Saran}

Berdasarkan penjabaran diatas, penulis memberikan beberapa saran terkait permasalahan tersebut yaitu: Pertama, Seharusnya pemerintah tidak melaksanakan PILKADA serentak di tahun 2020. Sebagaimana melalui mekanisme yang diatur pada Undang-Undang Nomor 8 Tahun 2015 dan Peraturan Pemerintah No 6 tahun 2005, penundaan tersebut dimungkinkan. Terkait adanya kekosongan kursi kepala daerah pada dasarnya sudah diatur pada konstitusi, yaitu: kekosongan pada jabatan Gubernur, maka akan diangkat Penjabat Gubernur yang berasal dari jabatan pimpinan tinggi madya. Kedua, Kekosongan jabatan bupati dan walikota, diangkat Penjabat Bupati Walikota yang berasal dari jabatan pimpinan tinggi pratama Sebagaimana ketentuan ini diatur dalam Pasal 1 angka 115 Undang-Undang Nomor 8 Tahun 2015 tentang Perubahan Atas Undang-Undang Nomor 1 Tahun 2015 tentang Penetapan Peraturan Pemerintah Pengganti Undang-Undang Nomor 1 Tahun 2014 tentang Pemilihan Gubernur, Bupati, dan Walikota menjadi Undang-Undang. Ketiga, masing-masing masa jabatan yang diberikan pada penjabat sementara ialah 1 tahun sesuai dengan ketentuan pasal 132 ayat (4) Peraturan Pemerintah Nomor 6 tahun 2005 yang telah mengalami 4 kali perubahan. Sehingga pemerintah masih memiliki waktu 1 (satu) tahun untuk menyiapkan mekanisme pelaksanaan Pilkada dengan baik. Ke-empat, Apabila pada kenyataannya tidak ada penjabat kepala daerah yang dapat mengisi kursi kepala daerah, maka dapat menunjuk sekretaris daerah menjadi penjabat kepala daerah sebagaimana ditentukan pada pasal 132 ayat (2) Peraturan Pemerintah Nomor 6 Tahun 2005.
Jurnal Yustika Vol. 24 No. 02, Des 2021

Halaman | 100 Refleksi Pelaksanaan Pilkada Serentak 2020: Suatu Kajian Tentang Demokrasi di Indonesia

Igam Arya Wada 
Jurnal Yustiko

Vol. 24 No. 02, Des 2021

Halaman | 101

Refleksi

Pelaksanaan

Pilkada Serentak 2020: Suatu Kajian Tentang Demokrasi di Indonesia

Igam Arya Wada

Selain itu, berkaitan dengan tetap dilaksanakannya Pilkada 2020 seharusnya dibarengi dengan regulasi yang jelas, baik terkait pelaksanaan PILKADA 2020 ditengah pandemi dan mekanisme pelaksanaannya. Sehingga tidak menimbulkan banyak pelanggaran terhadap protokol kesehatan. Berkaitan dengan hal ini, mencabut Perpu No 2 Tahun 2020 dan Membuat Perpu baru terkait penundaan Pilkada hingga 2021. Hal ini dikarenakan Perpu No 2 tahun 2020 bertentangan dengan tindakan pemerintah yang melaksanakan Pilkada disaat pandemi Covid-19. Sehingga akan lebih baik jika pelaksanaan Pilkada didukung dengan aturan hukum yang sejalan. Selain itu, Pemerintah sebelum membuka pendaftaran seharusnya sudah mengeluarkan aturan hukum terlebih dahulu seperti merevisi Undang-Undang Pilkada berkaitan dengan pelarangan kampanye dengan konsep mengumpulkan masa atau kerumunan selama masih ada pandemi. Membuat Undang-Undang tentang Covid yang mengatur terkait protokol kesehatan dan sanksi bagi pelanggar juga merevisi Peraturan KPU terkait pelaksanaan Pilkada ditengah pandemi juga merupakan solusi yang patut dipertimbangakan. Beberapa hal lain yaitu terkait adanya sosialisasi dan simulasi terlebih dahulu terkait mekanisme pelaksanaan PILKADA kepada masyarakat.

\section{Daftar Referensi}

\section{Peraturan Perundang-Undangan:}

Undang-Undang Dasar Negara Republik Indonesia Tahun 1945

Peraturan Pemerintah Pengganti Undang-Undang (Perpu) Nomor 2 Tahun 2020 tentang Perubahan Ketiga atas Undang-Undang Nomor 1 Tahun 2015 tentang Penetapan Peraturan Pemerintah Pengganti Undang-Undang Nomor 1 Tahun 2014 tentang Pemilihan Gubernur, Bupati, dan Walikota Menjadi Undang-Undang

Undang-Undang Nomor 10 Tahun 2016 tentang perubahan kedua atas Undang-Undang Nomor 1 Tahun 2015 tentang Pemilihan Gubernur, Bupati, dan Walikota.

Undang-Undang Nomor 1 Tahun 2015 tentang Penetapan Peraturan Pemerintah Pengganti Undang-Undang Nomor 1 Tahun 2014 tentang Pemilihan Gubernur, Bupati, dan Walikota Menjadi Undang-Undang

\section{Buku:}

Abdul Ghofur, Demokrasi dan Prospek Hukum Islam di Indonesia, PT. Bumi Wali Songo 2002

Merphin Panjaitan, Gerakan Warga Negara Menuju Demokrasi, Jakarta, 2001

M.R Khirul Muluk, 2005, Desentralisasi dan Pemerintahan Daerah, Bayumedia Publishing, Malang.

Sidney Hook dalam Nakamura dan Samallowood, The Polities of Policy Implementation, st. Martin's Press, New York, 1980.

Jurnal:

Achmad Arifulloh. Pelaksanaan PILKADA Serentak yang Demokratis, Damai dan Bermartabat. Jurnal Pembaruan Hukum, Vol II, No 2. 2015 
Moch Halim Sukur, Bayu Kurniadi, Haris, Ray Faradillahisari N. Penanganan Pelayanan Kesehatan Di Masa Pandemi Covid-19 Dalam Perspektif Hukum Kesehatan. Journal Inicio Legis Volume 1 Nomor 1 Oktober 2020.

Muhamad Azhar. Partisipasi Masyarakat Dalam Penyelengaraan Pemilihan Kepala Daerah. Administrative Law \& Governance Journal. Vol. 1, No. 2, 2018.

Ni Ketut Arniti. Partisipasi Politik Masyarakat Dalam Pemilihan Umum Legislatif Kota Denpasar. Jurnal Ilmiah Dinamika Sosial, Vol. 4, No. 2, 2020.

Mohammad Mulyadi. Membangun Demokrasi Dengan Partisipasi Masyarakat Dalam Memilih Pada Pemilu 2019. INFO, Kajian Singkat Terhadap Isu Aktual dan Strategis. Vol. XI, No. 09, 2019.

Aprista Ristyawati. Efektifitas Pelaksanaan Pilkada Serentak 2020 Pada Masa Pandemi Darurat Covid-19 di Indonesia. Jurnal Crepido. Vol 02, No. 02, 2020.

Jurnal Yustika Vol. 24 No. 02, Des 2021

Halaman | 102 Refleksi Pelaksanaan Pilkada Serentak 2020: Suatu Kajian Tentang Demokrasi di Indonesia Igam Arya Wada

\section{Sumber Internet:}

JPPN, Bawaslu Temukan Banyak Masalah di Hari Pencoblosan Pilkada, Ada soal COVID19,Online:,https:// www.jpnn.com/news/bawaslu-temukan-banyak-masalah-di-haripencoblosan-Pilkada-ada-soal-covid-19

Kompas, Nasional, Mengenal Covid-19 dan Pemulihan Ekonomi Nasional Online: https://nasional.kompas.com/read/2020/07/21/10434871/mengenal-komite-covid-19dan-pemulihan-ekonomi-nasional-jurus-baru-jokowi?page=all.

Kompas, Nasional, Tak Setuju Pilkada 2020 tetap di Gelar, Online: https://nasional.kompas.com/read/2020/07/22/19585541/charta-politika-542-persen responden-tak-setuju-Pilkada-2020-tetap-digelar. Diakses pada minggu 14 maret 2021

Liputan, KPU Pertahnkan Target Partisipasi Pemilih Pilkada Walaupun Pandemi Covid-19, Online:https:// www.liputan6.com/Pilkada/read/4421231/kpu-pertahankan-targetpartisipasi-pemilih-Pilkada-walaupun-pandemi-covid-19. Diakses pada 14 maret 2021

https://nasional.kompas.com/read/2020/09/06/22574571/bawaslu-2-hari-pendaftaranpilkada-ada-243-dugaan-pelanggaran-protokol?page=all 